\title{
A COMPARISON OF THE CONCEPT OF ROMANTIC LOVE IN THE NOVELS AYAT-AYAT CINTA 2 AND SALJU SAKINAH
}

\section{(Perbandingan Konsep Cinta Romantisme dalam Novel Ayat- ayat Cinta 2 dan Salju Sakinah)}

Koh Young Hun

yhkoh21@empal.com

Ummi Hani Abu Hassan

ummihani.abuhassan@yahoo.com.my

Department of Malay-Indonesia, Hankuk University of Foreign Studies.

Published on: 1 June 2018

To cite: Koh Young Hun and Ummi Hani Abu Hassan. (2018). A comparison of the concept of romantic love in the novels Ayat-ayat Cinta 2 and Salju Sakinah. Malay Literature 31(1), 98-123.

\begin{abstract}
This study uses textual analysis to explore the concept of romantic love by comparing the Indonesian Islamic novel, Ayat-ayat Cinta 2, by Habiburrahman El-Shirazy with the Malaysian Islamic novel, Salju Sakinah, by Zaid Akhtar. This investigation utilises the Theory of Persuratan Baru by focusing on the concept of the nature and function of literature. This study discovers that the creation of novels infused with Islamic elements and romantic love in Indonesia and Malaysia is influenced by two main factors, which are the awareness of the writer to disseminate Islamic messages and the profit motive of the publisher. These two factors cause novels, imbued with Islamic elements and romantic love, to become a branded or marketable commodity in both countries. The findings reveal that Ayat-ayat Cinta 2 utilises the concept of romantic love with emphasis on sexual intimacy while Salju Sakinah places emphasis on the language of understanding over physical intimacy.
\end{abstract}


Keywords: Islamic novels, Ayat-ayat Cinta 2, Salju Sakinah, romantic love, sexuality.

\begin{abstract}
Abstrak
Kajian ini meneroka konsep cinta romantisme dengan kaedah analisis teks dan perbandingan antara novel Islam Indonesia dengan novel Islam Malaysia. Kajian memilih novel Ayat-ayat Cinta 2 oleh Habiburrahman El-Shirazy dan novel Salju Sakinah oleh Zaid Akhtar. Penelitian ini menggunakan Teori Persuratan Baru dengan memberi penekanan terhadap Konsep Hakikat dan Fungsi Sastera. Kajian mendapati kelahiran novel berunsurkan Islam dan cinta romantisme di Indonesia dan Malaysia didorongi dua faktor utama, iaitu kesedaran penulis menyampaikan mesej Islam dan kehendak penerbit yang mahukan keuntungan. Dua faktor ini menyebabkan novel berunsurkan Islam dan cinta romantisme menjadi jenama atau produk pasaran di kedua negara. Hasil analisis menunjukkan novel Ayat-ayat Cinta 2 menggunakan konsep cinta romantisme yang berorientasikan seksual, manakala novel Salju Sakinah mementingkan bahasa nurani berbanding sentuhan fizikal.
\end{abstract}

Kata Kunci: novel Islam, Ayat-ayat Cinta 2, Salju Sakinah, cinta romantisme, seksualiti

\title{
INTRODUCTION
}

Love is an emotion that binds people regardless of differences in race, sex, class or social status. It also captures the human reality of Man as it develops over time. These pure attributes of love often become a theme in traditional and modern literature. One of the themes of love that has created controversy in Islamic society is romantic love. There are groups who either reject or accept the concept of romantic love in Islamic literature since its emergence in the 10th century.

Generally, before the advent of Islam in Mecca, pagan Arab society initiated literary activities such as poetry that extolled tribal communities, war triumphs, ancestral pride, important personages and tribal warriors as well as showed reverence for the women of their desires. Such literary activities were conducted through oral means and memory. In fact, street literature (suq al-Adab) became the platform for pagan Arab society to compete with one another on their poetry recitation (Moch Yunus, 2015, p. 1-2). When Islam first spread in Mecca, Allah SWT revealed the Qur'an to 
Prophet Muhammad SAW using high Arabic literature in order to transmit truth (M. Quraish Shihab, 1996, p. 7). Literature is a major artistic feature of the Qur'an. Every line, alphabet and word contained within it is a beauty beyond human capacity. Qur'anic literature aims to cleanse Man's soul, internally or externally, as well as to stress on human interaction for universal benefit (Nurazmi, 1991, p. 3).

The descent of the Qur'an precipitated a new episode in Man's literary activity. The Qur'an distinguishes poets into two groups, which are pious poets and deviant poets, as revealed in verses 224 until 227 of Surah asy-Syu 'ara:

And the poets were followed by the deviant people. Can you not witness that they are wandering in every valley, and that they like to preach what they do not practise? With the exception of those (poets) who are pious and devout and who invoke Allah's name immensely and achieve victory after enduring tyranny. And the tyrants will soon know where they will return to. ${ }^{1}$

(Tafsir Al-Azhar, 2018, p. 232)

Poets or artists receive special attention from Allah SWT due to their ability to arrange beautiful words that enchant or inspire people's hearts. They have the capacity to lead Man towards either a deviant or true path. Islam permits poets who advocate belief in the oneness of Allah as reflected in the above verse (Hamka, 2017, pp. 232-238). The recognition of Islam towards poetic activities resulted in the development of the literary field in tandem with the spread of Islam across the world. One of the main topics written by Islamic poets is on love (Md Ataur, 2010, p. 68).

\section{ROMANTIC LOVE IN ISLAMIC LITERATURE}

Abu Bakar Muhammad Ibn Dawud al-Asbahani wrote a book on the concept of love in the ninth century AD. This book is regarded as a book of philosophy and the earliest theory of love in the history of Islam (Basma and Hala, 2012, p. 227). The concept of love presented by Ibn Dawud is based on Islamic and intellectual brotherhood. He did not extend the concept of love to include the romantic relationship between men and women. Instead, love, according to him, must traverse the paths of patience, secrecy and submission towards Allah SWT. The writing on the concept of love that sparked controversy appeared in the 11th century in Ibn Hazm's book, Tawq al-Hamamah. This 
work combined individual anecdotes and an autobiography alongside a more liberated philosophy of love (Levy, 2013, p. 16). The writer associated love with women's beauty, erotic desires, kisses between lovers, infatuation and longingness in love. Levy (2013, p. 22, 30) also listed several other writers during the Abbasid era who had explored the concept of romantic love, including al-Washsha in his book, al-Muwashsha. Al-Washsha stated:

These last twenty chapters attest to the function of poetry in a so-called "courtly love" context: in order to achieve the elegant ideal, a man must be in love, and in order to behave properly in love, he must be acquainted with apt poems for use in all contexts of courtship.

Al-Washsha also depicted the story of a young man who falls in love with a young woman through their eyes in his poems. To him, the nobility and poets of that time appeared to be elegant in their expression of love towards their beloved. The eyes are regarded as an instrument that evokes the sensuality of romantic love. Ibn Hazm wrote about the eyes and the sensuality of love in his poem, "Fa-laysa li-'aynī 'inda ghayirki mawqif": "My eyes do not have a resting place except to gaze into you" (Isabelle Charlotte Levy, 2013, p. 35). Ibn Hazm's work touches on the relationship between the feelings of love and physical sensuality, which was eventually emulated by other poets during that era. Prior to this, Muslim poets in the 10th century were attracted to the legend of Qays al-Mulawwah's love-popularly known as "Layla and Majnun". According to Khairallah As'sad (1980, pp. 64-68), the character of Majnun is said to be a pre-Islamic legendary symbol of love that had influenced the literature of pagan Arabs until the 13th century. Among the figures who wrote about Majnun's madness of love towards Layla are Ibn Qutaybah (d. 889AD), al-Jahiz (d. 868 AD), Ibn Dawud (d. 910 AD) and al-Faraghi (d. 967 AD). ${ }^{2}$ Majnun etches Layla's name in his poetry after they met and fell deeply in love in their youth (Khairallah As'sad, 1980, p. 86). The eyes became a tool of love, which rendered Majnun incapable of forgetting Layla and eventually succumbing to madness upon their separation. As mentioned by Majnun in his poem: "Oh my (two) friends, my Paradise is Layla, my Hell is her distance, and when I want to pray, she is my object of devotion" (Khairallah As'sad, 1980, p. 91).

However, there are Islamic scholars who have rejected works of romantic love. Just as the Qur'an categorizes poets into pious poets and deviant poets, a group of Islamic scholars have purged the concept of love among elements 
that are not found in the Qur' an and the hadith of Prophet Muhammad SAW. In the 14th century, Ibn Qayyim Al-Jawziyya wrote a book entitled Rawdat al-Muhibbin (The Garden of the Lovers) to reclaim the sanctity of love, which is love for God, by disallowing the incorporation of romantic love and physical sensuality. Although his formulation of the terminology of love has been employed by Islamic scholars for four centuries before him, he rearranged the discussion of the concept of love in accordance with his school of thought as follows:

Ibn Qayyim was a Hanbalī jurist whose ideas of language are strongly influenced by theories about the reality of the divine attributes (șifât) relation to God's essence propounded by his teacher the famed Ibn Taymiyya. His list of fifty words was intended to demonstrate how each of these words (and these words alone) related to love's essence: at once physical, mental states, short lived, and long-lasting.

(Pomerantz, 2015, pp. 4-6)

Ibn Qayyim upheld the views of his teacher, Ibn Taymiyyah, who rejected sensual love or ishq', which can result in devotion to living beings. In fact, this term is not found in the relationship of love between living beings and God as it is excessive and negative (Pavlin, 1998, p. 266). Ibn Taymiyyah said that a Muslim needs to perfect his love for Allah SWT and His Prophet in order to savour the sweetness of faith: "love for the beloved things of the beloved one is an aspect of completing the love of the beloved one" (Pavlin, 1998, p. 266).

Ibn Taymiyyah stated that a person must prove his love for Allah SWT and His Prophet by loving what God loves and avoiding what God hates. Hence, Man must strive against emotions that diminish his love for God, including excessive love for another human being. According to Ibn Taymiyyah, this struggle is a form of jihad (Pavlin, 1998, pp. 273-274). Ibn Taymiyyah and Ibn Qayyim rejected Ibn Hazm's work, Tawq al-Hamamah, which they believed has flouted Islamic sharia, as evident in the chapter on the secret meeting between lovers, the sensual gazing of lovers and caresses between unmarried couples. Ibn Qayyim al-Jawzi also wrote a book, Dzam al-Hawa, to explain the dangers of lustful desires in Man (Md. Ataur Rahman, 2010, p. 99).

It is also interesting to discuss the concept of romantic love in Islamic literature after the crusades and European colonisation of Muslim-majority 
countries from the 18th to the 20th century. The clash resulted in the influence of European literature seeping into the works of Islamic writers, especially in Egypt, and later spreading into other Islamic countries, including Malaysia and Indonesia. Ghada al-Ghamdi (2013, p. 2) said that the main cause of influence of European literature in the Islamic world was the printing press. This device was created in the West in the 15th century but was first introduced to the Arab world in 1821. Translations that were carried out since the Abbasid era had increased, particularly the translation of English, French, German, Italian and Russian novels into the Arabic language (Ghada Al-Ghamdi, 2013, pp. 2-3:

Everything changed almost overnight, and the eastern readers turned out to be almost as hungry for inexpensive books as their counterparts in the west had been nearly four hundred years earlier.

The novel is a new form of literature in the Islamic civilisation, which was broken into countries after Western colonisation. In Egypt, Western novels with themes of romantic love, history, travelogue and social justice influenced the local writers. They translated and adapted Western ideas that were regarded as a new wave of thinking and suitable for imitation by Eastern society (Ghada al-Ghamdi, 2013, p. 4). The first novelist in Egypt was Husayn Haykal (1888-1956). He wrote the novel, Zaynab (1911), while studying in Sorbonne, France (Smith, 1979, p. 249). He wrote on the theme of love in order to reform Egyptian society with a progressive Western perspective. To him, love signifies individual freedom and rational consciousness. Through Zaynab, Husayn Haykal emphasized on Egypt's social issues, among which included the low level of women's education and arranged marriages. He opposed an imbalanced romantic relationship in which women were not granted the freedom to celebrate their love as men did, which eventually culminated into a relationship that Husayn Haykal termed as soul and corpse. Apart from the intrinsic nature of love, Husayn Haykal also promoted sensual elements that were still considered alien to the domestic social realities of Egypt of that time (Smith, 1979, pp. 250-253). His excitement towards Western ideas, including those of the French philosopher, Jean-Jacques Rousseau, motivated him to repeat the depiction of physical relationships as written by Muslim authors during the Arab Middle Ages.

The first Malay novelist, Syed Sheikh Ahmad al-Hadi (1867-1934), adopted Husayn Haykal's approach. The study by Rosni and Normazla (2013, 
p. 139) shows that the theme of Syed Sheikh Ahmad al-Hadi's novel, entitled Hikayat Faridah Hanom (1926), is similar to Zaynab. It is interesting to note here that Husayn Haykal and al-Hadi were supporters of the Islamic Reform conceived by Muhammad Abduh. In the spirit of reform, both deployed the theme of romantic love in their respective novels in order to criticise local traditions that were based on Islam.

During their courtship, they upheld their self chastity and family honour by preserving their modesty and never going overboard. For instance, when they were together on horse carriage to isolated places, a servant would always act as a chaperone to them. To exemplify further, in an instance when Faridah Hanom tried to test Syafiq Afendi's self-preservation and true love, she wore a revealing, skin coloured outfit that seemed as if she was nude.

(Rosni and Normazla, 2013, p. 142)

Marah Rusli also used the theme of romantic love in his novel, Sitti Nurbaya (1922), in order to criticise Minangkabau tradition as well as Dutch colonisation. This novel is said to be the first Indonesian novel written, according to literary scholar, Teeuw (Yeni Mulyani, 2010, p. 797). In contrast to al-Hadi, who was greatly influenced by Egypt's early novels, Marah Rusli's inclination towards Western novels was due to his educational background in Nederlands Indische Veeeartsenjis School (Dian Nathalia Inda, 2015, p. 218). This fact shows that early novels in Malaysia and Indonesia were more influenced by Western romantic love despite the popularity of this theme in Islamic literature during the Abbasid era. As written by Husayn Haykal, al-Hadi and Marah Rusli also conveyed Islamic messages in their novels as well as controversial aspects of romantic love such as sensuality as well as the interaction and physical relationship between lovers.

\section{ROMANTIC LOVE IN ISLAMIC NOVELS IN INDONESIA AND MALAYSIA}

Early novels in Malaysia and Indonesia presented themes of love laced with modest Islamic elements. This occurred for two main reasons: the social criticism of the writers towards local tradition and culture as well as a strong economic appeal (Maier, 1993, p. 12; Mujiyanto and Amir Fuady 2014, pp. 33-34; Banks, 1987, pp. 2-20). 
The first serious novel to present an Islamic theme and romantic love was by Hamka. He was born on 17 February 1908 was the son of Abdul Karim Amrullah, a Muslim scholar and Islamic reformist from Minangkabau in the island of Sumatra, Indonesia. Between 1936 and 1939, Hamka wrote three novels that focus on love and Islam.

Teeuw (1967, pp. 69-72) contended that the contrast between Hamka and other novelists who originated from Sumatra at that time was that Hamka's early novels were not influenced by English or Dutch but rather modern Arab literature. ${ }^{3}$ His first novel, Di Bawah Lindungan Kaabah (DLK) (Balai Pustaka, 1936), recounts the tragic love that ends with the death of two lovers. This novel is unique as Islam is prioritised and, as such, it does not include any physical interaction between the characters who are deeply in love with each other. Romantic feelings among characters are expressed through opposing words, among which include "tall, short, happiness, sadness, laughter, lamentation, separation, elation, arguments and disputes, he is the sky, I'm the earth, gold and brass, silk and yarn".

The birth of Hamka's novel was a trying time for Indonesian society, including for those in Padang Panjang, a small town in West Sumatra. Dutch colonisation did not alter the life of the indigenous people. In fact, for the Padang Panjang people who were bound to the customary laws of Minangkabau, or Adat Pepatih, the economic disparity between tribes was still widespread (Leon Salim, 2010, pp. 22-30). This had indirectly affected individuals from different economic class who still loved each other. Hamka, as other novelists of Minang descent, depicted these customary practices that were oriented towards economic class as inhumane. In contrast to the reallife struggles against colonisation, through his novel, Hamka paid greater attention to the love story between a poor young man and a woman from a respectable tribe. Since the romance novel was introduced in Sumatra, it became popular and preferred by many. During this time, publishers in Indonesia encouraged the writing of stories with love themes and social crisis. ${ }^{4}$ Hamka, being a preacher, utilised the strategy of a love story in order to attract Indonesian society to Islam so as not to breach Dutch colonial policy in an overt manner. However, he used religion as a character's endurance factor when confronting love. This is also observed in his following novels, Tenggelamnya Kapal Van de Wijck (TKVDW) (Balai Pustaka, 1937) and Merantau ke Deli (MKD) (Cerdas Medan, 1941).

This study is of the opinion that Hamka, who was educated in the Islamic Reformist School of Theology (madrasah), was prepared to refine Islamic 
teachings from transgressions of customary practices. He envisioned love as a form of strength within an individual. Characters such as Hamid and Zainab (DLK), Zainudin and Hayati (TKVDW) and Leman and Poniem (MKD) are Indonesian teenagers who possess commitment and resolution to liberate Indonesia but were eventually defeated and later sacrificed after being dejected by love. Hamka believed such situations to be damaging to Indonesian Muslims and one way to overcome this dejection is to return to the teachings of Islam and love for the Almighty God.

Hamka's solemnity affected discussions on Islamic literature in Malaysia. In 1954, Ramsa Asmara initiated a debate on the concept of Islamic literature when he wrote the article entitled "Literature and Religion" in Jurnal Guru. He asserted that literary expression must adhere to the concept of Islam, reflect the reality of Muslims and show aspects of language reform by combining simplicity and clarity. In this matter, he presented Hamka's personality as a model for the Muslim world for successfully inspiring the spirit of Islam and literary creativity (Rosni, 2013, p. 1082). However, from the 1960s until the 1990s, the majority of Malaysian novelists still marginalised Islamic values in their works.

Mohd Zariat's (2011) study shows that the majority of Malay novels tend to apply Western literary practices. The theme of love contains sexual elements that are not consonant with Islamic values; such examples include Terdedah (1965), Kuala Lumpur Kita Punya (1967), Bila Hujan Malam (1976), Salina (1976), Langit Petang (1982), Sakura Mengorak Kelopak (1987) and Tok Guru (1988). Meanwhile, the majority of Islamic-oriented novels that were published through competitions $\mathrm{s}^{5}$ and contests also included unreasonable sexual elements. Kamariah (2011, p. 627) examined 16 Islamicoriented Malay novels and stated:

The eroding effectiveness of Islamic values is clearly shown due to the portrayal of characters that did not attain the value of mindfulness at the end of the story. This causes the virtuous message to recede; the focus on love between men-women made more apparent; with the plot exhibiting planned sexual elements in order to arouse the reader's sensual feelings as in the novels Bahimiyah (1988), Masuk ke dalam Cahaya (1997), Daerah Asing (1987), Hidayah (1999), Nurul Hidayah (1988), Mengejar Kedamaian (t.t.), Mentari di Ambang Senja (1985), Jalan Seribu Liku (1999) dan Arbain (1985). 
The portrayal of pre-marital love inclusive of sexual elements entices these novels even though the main message is Islamic teachings. Kamariah (2011, p. 628) coined the term "intoxicated fervour" for the concept of pre-marital love between men and women, a characteristic that is absent in Islamic literature.

In Indonesia, Islamic and romance novels were in short supply between the 1960s and 1980s. As a result of changes in the economic policy and, concomitantly, an increase in foreign investment, the publication of Islamic novels spiked in the 1970s and 1980s. However, Islamic publishers who emerged during this time published more magazines, newspapers and reference books on Islam (Watson, 2005, pp. 177-210). ${ }^{6}$ In contrast, towards the end of the 1990s, novels with Islamic themes and love became a phenomenon due to two main factors. Firstly, arising from the emergence of "fragrant literature" after the downfall of President Suharto, Indonesia's erotic liberal writers such as Ayu Utami, Djenar Maesa Ayu and Dewi Sartika began to appear.

Fragrant literary writers have been successful in attracting a large number of readers based on their high sales record (Mohd Zariat, 2012, p. 59). In response, writers from the Forum Lingkar Pena (FLP) group foregrounded the Islamic romance novel that challenges the themes of "fragrant literature".

The founder of FLP, Helvy Tiana Rosa, explained that love according to Islam is universal and should not lead readers to negligence. Islamic literature should highlight love that is built on faith and morality (Arnez, 2009, pp. 45-64). This principle became the basis of writers under the patronage of FLP, including the novelist of Ayat-ayat Cinta (henceforth referred to as $A A C$, 2004), Habiburrahman. Arnez (2009) and Mohd Zariat (2012) both agree that $A A C$ sparked the phenomenon of milieu of Islamic romance novels in Indonesia. The sales of $A A C$ profited the Republic after the novel was reprinted 35 times with a sales figure of 700 thousand copies within two years of its publication $(2012$, p. 61). This situation created opportunities for other publishers to emulate $A A C$, especially in terms of its title, illustrations and notes on the novel's cover, the style of the writer's name, themes and characterisation that are linked to Islam and romance elements.

In addition, the novel's cover illustrates an Islamic message with romance elements such as the beautiful eyes of a young woman and a young man in a skullcap. Such images help to explain the personality of the main characters: a beautiful young woman who is devout and a young handsome man who is pious. In addition, beneath this image appears the following 
Islamic themes: Novel Spiritual Pembangunan Iman (A Spiritual Novel that Builds Faith), Sebuah Novel Religius (A Religious Novel), Sebuah Novel Religius Pembimbing Jiwa-Jiwa Pencinta (A Religious Novel that Guides the Souls of Lovers), Sebuah Novel Spiritual Keajaiban Cinta (Magical Spiritual Love Novel) and Sebuah Novel Pembangun Jiwa (A Builder of Souls Novel). Other similarities detected include the "Best Seller" title placed on the cover of the novel and the commercial line such as 20000 copies of this novel sold, which will pique the interest of buyers. From 2007 until 2016, approximately 381 novels of Islamic themes and romance were published by the main Indonesian publisher. The inclination of publishers to determine themes, titles and number of pages is linked to marketing and profits, more so when a publisher produces Islamic romance and non-Islamic novels in one publication.

Secondly, the wave of Islamic and romance novels is also caused by post-Islamisation in society. In 1962, Indonesia created space for Western popular culture when television first appeared in the country, which has one of the largest Muslim population in the world (Weintraub, 2011, p. 50). Researchers of local culture such as Heryanto and Ishadi S.K (2011) believed that Western media influenced the birth of popular Islamic culture. In the 1980s, Islam was not foregrounded in terms of wealth and modernity. Instead, freedom of the press in Indonesia witnessed the emergence of a new culture, including popular Islam that is linked to the Islamic romance novel. For example, after $A A C$, Habiburrahman further produced seven novels that preserved Islamic themes and romance such as Ketika Cinta Bertasbih 1 (2007), Ketika Cinta Bertasbih 2 (2007), Dalam Mihrab Cinta (2008), Bumi Cinta (2010), Cinta Suci Zahrana (2011), Api Tauhid (2015) and Ayat-ayat Cinta 2 (2015). Four of his novels were adapted into films and soap operas with the lead characters being a handsome young man and a beautiful young woman in compliance with an Islamic image. The message of the novels that is transmitted through the screen continues to heighten the phenomenon of post-Islamisation in Indonesia until today.

It is interesting to stress here that the phenomenon of Islamic and romance novels in Malaysia in the 2000s was influenced by the developments in Indonesia after these novels were translated into the Malay language and sold in Malaysia. On 30th May 2006, the company that distributed Islamic books in Malaysia, Hidayah Publisher, obtained printing rights and distributed all of Habiburrahman's novels in Malaysia, Singapore, Brunei and in certain parts of the Philippines (Anif Sirsaeba, 2006, p. 141). The high sales and ratings 
subsequently motivated other publishers to publish Islamic romance novels, just as in Indonesia. For example, PTS Sdn Bhd published Salju Sakinah (2008) by Zaid Akhtar, Warkah Cinta Berbau Syurga (2008) and Kala Cinta dan Wahyu Bersatu (2013) by A. Ubaidillah Alias, Hidayah Cinta (2008) by Ilham Hamdani, Bukan Yang Pertama (2008) by Salina Ibrahim and Kuntum Cinta di Taman Syurga (2014) by Thoyba Mursyidah. The concept of love in these novels are more constraining as it prohibits free socialisation between young female and male characters. In fact, love between these characters is related to Islamic teachings such as prayer, hope and propriety. Subsequently, the concept of love is made evident externally through the titles, illustrations and notes on the book covers. In his study, Mohd Zariat (2014, pp. 417-433) shows that a vast majority use Arabic words to further signify the Islamic faith such as sakinah, hidayah, Ya Fattah, khalifah, syahadah, mahar and An-Nur. These novel titles are accompanied with Islamic images such as a veiled beautiful woman, a handsome man with a skullcap, mosques, the Kaaba, the Qur'an and Arabic calligraphy. In contrast to the publication of Malay Islamic novels and romance in the 1920s, this genre is currently loaded with Islamic images unbounded by the ideas of Kaum Muda (The Young faction) or Kaum Tua (The Old faction). Publishers are more concerned about profit and exercise caution in criticising religious policies implemented in Malaysia. Moreover, current highly-educated authors are able to produce better writings compared to novelists who wrote before Independence.

Based on the above discussion, this study finds that Islamic and romance novels in Indonesia and Malaysia have a connection with each other. Firstly, the birth of Islamic and romance novels in Indonesia and Malaysia was the result of Western influence. Secondly, this genre of novel grew rapidly in Indonesia and later influenced its emergence in Malaysia. This happened when Hamka's novels were regarded as exemplary Islamic works to be emulated by Malaysian writers. Also, the publication of Ayat-ayat Cinta (2004) stimulated the rebranding of Islamic and romance novels in the 2000s. Thirdly, publishers who put premium before profit whilst spreading the message of Islam to society supported the distribution of such novels since before Independence until today.

\section{ANALYSIS OF ROMANTIC LOVE BASED ON THE NATURE AND FUNCTION OF LITERATURE}

The nature and function of literature constitutes an extension of the nature of man, the nature of knowledge and action in the theory of persuratan baru. ${ }^{7}$ 
Literature is the story of mankind, produced by mankind, for the purpose of mankind and the path of faith. It provides an understanding of one's responsibility as a servant and vicegerent of Allah SWT (Mohd Affandi, 1992, p. 23). This reflection promotes literature as an act of devotion (ibadah) and propagation of belief (dakwah).

Ayat-ayat Cinta 2 (henceforth referred to as $A A C 2$ ) focuses on the character of Fahri and Aisha or Sabina (they are one and the same). Marriage permits Fahri's feelings of excessive yearning and passion towards Aisha. This study sees the martial relationship as being consonant with the nature and function of literature. However, this study finds that there are two approaches of Fahri's love towards Aisha. In the first aspect, Fahri's frequent thoughts of Aisha causes him to fantasize and lose himself in sensual longing. Aisha is depicted as being beautiful and adept at sexually arousing Fahri. Among the ways that Aisha seduces her husband to have sex with her is by wearing nightgowns, playing the violin, dabbing perfume, looking at him with desirous intentions and reciting the poem "Kekasih" (Lover) by Paul Eluard. The following situation shows his sexual desire enticed: Aisha menyudahi nadanya, ketika Fahri sampai puncak mabuknya. Seperti biasa, sama seperti saat malam pertama di Kairo, Aisha membacakan puisinya ... [Aisha completes her tone, when Fahri reaches the climax of his drunken state. As usual, similar to the first night in Cairo, Aisha recites her poem] (AAC2, p. 19).

The elaboration of Fahri's sensual feelings towards Aisha brings the reader closer to the depiction of sex, which will take place within this marital relationship. Although the author sanctifies Fahri and Aisha's relationship in a marriage bond, bedroom acts, however, do not quite fit the concept of knowledge that forms the basis of the nature and function of literature. Mohd Zariat (2011, p. 155) states that the function of knowledge is to establish truth to ultimately bring Man closer to Allah SWT. On the contrary, a detailed explanation of Fahri's feelings is more appropriate to the Western concept of love proposed by Kern (1992), which is love that is often portrayed through moments of close encounter, embodiment, sexual desire, disclosure and kissing.

In fact, the formulation of the phrase "the first night" without the accompaniment of a detailed depiction can itself explain an intimate marital relationship. According to Mohd Zariat (2011,pp. 202-203), sexual philosophy in Islam comprises of a bond that will bring both a husband and wife to Allah SWT by shielding their intimate parts from indecent and evil acts. 
However, when the relationship is meticulously described in a literary text, its interpretation by readers can be transformed into eroticism, which can prevent them from being closer to Allah SWT. In addition, the nature and function of literature stresses on suitable language following the mould of Qur'anic language that prioritises aspects of content and meaning. The Qur'an utilises refined metaphors, especially when describing marital relationship, such as in verse 223 of Surah al-Baqarah, which states: "Your wives are a place of sowing of seed for you, so come to your place of cultivation however you wish'. And put forth [righteousness] for yourselves. And fear Allah and know that you will meet Him".

Conversely and unashamedly, in $A A C 2$, it is through Fahri's reflection that Aisha's seduction to engage in sex is related. Aisha hugs, whimpers and kisses Fahri's neck until it pushes Fahri to have sex with his wife $(A A C 2$, p. 64). A subsequent event shows Aisha removing Fahri's clothes and massaging him to sleep: "Dan siang itu dirinya dilucuti oleh Aisha untuk dipijat dan disegarkan dengan spa hingga dirinya tertidur" ["In daytime, he is stripped by Aisha to be massaged and refreshed with mineral rich spring water till he slept"] (AAC2, p. 22).

The word dilucuti (stripped) conveys the idea of removing one's attire, which does not reflect Islamic literary truth. The author puts a stop to Aisha's seduction of Fahri with the phrase "bidadari yang telah membuang rasa malunya" [the angel who had quelled her shame] and "memberikan yang terbaik saat beribadah bersama suaminya" [to give her best in devoting (beribadah) herself to her husband]. It is felt that the words "to give her best in devoting herself to her husband" is sufficient to clarify the physical intimacy between Aisha and Fahri. However, these words are used to conclude the sensual chapters which can be found in pages 21 and 22 of this novel. Subsequently, Aisha shows courage in foretelling Fahri's sexual desire: "Lebih bergetar mana memasuki kamar ini, atau kamar Hotel San Stefano?" ["Which is more quivering, to enter this room or the room in Hotel San Stefano?"] ( $A A C 2$, p. 343).

Aisha's question is understood as a wife's wish to satisfy her husband's sexual desires. In a subsequent scene, after performing wudu (ablutions), Aisha switches off the light, dabs perfume and recites poetry, which makes Fahri fervently impatient to sleep with his wife $(A A C 2, \mathrm{p} .44)$. The author also depicts Fahri and Aisha's passionate acts after a long yearning: "Aisha mendekatkan wajahnya pada wajah Fahri. Kini Fahri bisa merasakan hembusan nafas Aisha, hal yang sudah lama tidak ia rasakan" ["Aisha draws 
her face closer to Fahri's face. Now Fahri can feel Aisha's breath, one that he has not felt for a long time"] (AAC2, p. 690).

Based on the first view of Fahri and Aisha's relationship, the author projects a false reality according to the Theory of Persuratan Baru (Mohd. Affandi et al., 2008) as the portrayal of a man's sensuous power is confusing and contradicts the nature of truth in Islam. This is unlike natural reality that enables Man to understand and recognise the truth regarding their Creator through intellect and conscience. The explanation of sexual desire above does not correspond with the concept of true knowledge, which prioritises the selection of good words, noble behaviour and refraining from sexual pleasure. It is worrying that the author's inclination to portray sensual acts will cause confusion and misunderstanding to lay readers. With regard to the second view, the feelings of love between Fahri and Aisha are controlled by the selection of indirect words, which according to this study is wise. For example, when Fahri sees a pair of birds in love, it reminds him of himself: "Kalau Aisha ada di sisinya ia juga sering tidak sabar untuk mengajaknya beribadah dalam selimut sakinah, mawaddah war rahmah" ["If Aisha is by his side, he would be impatient to invite her to devote herself in the blanket of faith, affection and mercy"] (AAC2, p. 125).

Based on Fahri's condition, this study understands the phrase "impatient to invite her to devote (beribadah) herself" to mean "impatient to invite her to have sex". The author's refusal to overstate the intention of a sexual act in this part coincides with the nature and function of literature, which is to reject mimetic elements and false appearances in a literary work. Finally, the exemplary love between Fahri and Aisha shows that their love is not based on sensual and sexual desire but also the pursuit of truth. Although Fahri often longs for Aisha, which often causes him to fantasize on their sexual relationship, in other situations, he channels his longing by performing good deeds in her name ( $A A C 2$, p. 226). Associating love with aspects of divinity fulfils the nature and function of literature and is consonant with the aim of knowledge. Without illustrating physical form and physical intimacy between them, the reader can absorb the value of a beautiful romantic love in layers of devotion and good deeds. In fact, this second form of love can save Fahri from the impression that he loves Aisha on the sole basis of her ideal womanhood and ability to satisfy his sexual needs. Instead, Fahri's love towards Aisha is based on faith and truth.

Similar to his relationship with Aisha, Fahri's relationship with Hulya also begins with their marriage. This relationship is compatible with the 
philosophy of love in Islam in which only marriage legalises physical intimacy between men and women. Marriage is also important because the concept of romantic love projected in $A A C 2$ emphasises on the physical acts between Fahri and his wives.

This study maintains that, in reference to the above matter, $A A C 2$ positions Aisha and Hulya as characters that arouse Fahri's sexual instincts. Even though Hulya exists to fill the void left by Aisha, she is forced to follow in the latter's manner of seducing Fahri. The author also clearly shows Fahri's position as a virtuous man to the point that the beautiful and educated Hulya is willing to pursue Fahri's love and propose to him ( $A A C 2$, p. 594).

This study finds that there is no great effort on Fahri's part to accept Hulya without the blessing of Aisha's love. On Hulya's part, she is forced to perfect herself in order to be exceedingly special to Fahri compared to Aisha $(A A C 2$, p. 595). Fahri's reaction to question Hulya's hope to be better than Aisha is unbefitting of a knowledgeable and virtuous husband. In fact, his attitude is a manifestation of his ego and weakness as he is so accustomed to receiving enjoyment in the form of love, wealth and sexual gratification from Aisha that he unconsciously also expects the same from Hulya.

The following episode clarifies Hulya's efforts to arouse Fahri's sexual desires goes to the extent of choosing their honeymoon location and strategising to further gain Fahri's love.

"Aku suka sungai. Bulan madu di pinggir sungai bersejarah seperti ini bagiku sangat romantis. Aisha pernah cerita, katanya kalian dulu bulan madu di apartment mewah di pinggir Sungai Nil. Aku tidak mau kalah. Kemarilah, peluk aku sambil menikmati panorama Sungai Thames membelah London".

"I like rivers. Honeymooning on the edge of a historical river such as this, to me is quite romantic. Aisha once mentioned that you spent your honeymoon in a luxury apartment on the edge of the River Nile. I don't want to be outdone. Come to me, embrace me while appreciating the panoramic River Thames that severs London".

(AAC2, p. 597)

Fahri also fails to satisfy Hulya's sexual needs as a husband ( $A A C 2$, 598). In order to conceal his weakness, Fahri provides the following analogy: "Memetik buah jangan tergesa-gesa jika ingin hasil terbaik. Petiklah buah itu di puncak kematangannya, istriku!" ["One should not be in a hurry to 
pluck fruits if one desires a bountiful harvest. Pluck the fruit at the peak of its ripeness, my wife!'] ( $A A C 2$, p. 598).

Although such words make sense, according to this study, this is a form of escapism by Fahri who is unresponsive to Hulya's efforts. Instead, he uses his marital experience to gain Hulya's trust with regard to sex. For two months, Fahri does not fulfil his conjugal responsibility towards Hulya, revealing his huge weakness. This is further reinforced when Fahri suggests a divorce and Hulya hopes that she is simply being tested for her failure to share in household duties, which in fact should be Fahri's responsibility as a husband ( $A A C 2$, p. 604).

$A A C 2$ shows that Hulya puts in greater effort than Fahri in saving their marriage although the source of their conflict is Fahri. She begins by changing her attitude to be gentle and compassionate. She chooses a vacation (umrah) to Mecca and Madinah, and brings Fahri to camp, which culminates in Fahri having sexual intimacy with her ( $A A C 2$, pp. 606-608). Ironically, Fahri does not thank Hulya for her effort and this makes readers realise that Fahri is unaware of his injustice towards Hulya as though she is carrying out her responsibility as a husband in their family.

$A A C 2$ also presents romantic love as having achieved the peak of happiness after enjoying permissible sex. This is shown through Hulya's more positive and happy outlook after having had sexual intimacy with her husband:

Fahri begitu sabar dan telaten mengiringinya memasuki mihrab-mihrab kenikmatan ibadah (seks) yang menggetarkan seluruh syaraf-syarafnya. Berulang-ulang kali ia memekikkan tasbih di telinga Fahri dengan kedua mata terpejam. Harum kesturi mengiringi merekahnya jutaan bunga mawar yang indah di dalam batinnya

Fahri is so patient and participates in the pleasures of sex that tingle all her nerves. Repeatedly, she loudly utters her praises to God in Fahri's ears with both eyes closed. Fragrant scents accompany the splitting of a thousand beautiful roses in her inner self.

(AAC2, p. 610)

In fact, Hulya is portrayed as being "creative" in arousing sexual pleasure to the extent of willingly emulating the strategies used by Fahri's first wife, Aisha, by reciting the poem "Lover" by Paul Eluard. As mentioned previously, 
this poem becomes the determining factor for Fahri to climax during his sensual encounters with Aisha then and now with Hulnya:

Fahri tidak jadi mengakhiri ibadah (seks) itu, ia justeru memperpanjangkannya. Ia menghadirkan ribuan tasbih paling menggetarkan dalam setiap pori-pori dan syaraf-syaraf Hulya

[Fahri is not able to terminate his devotion (sex), so he lengthens it. He presents a thousand praises which send enormous tingling sensations to each of her pores and nerves.]

Based on the romantic relationship between Fahri and his two wives above, this study finds that the author smears the concept of the nature and function of literature by repeatedly presenting emphasis on the physical and sexual desires of a romantic relationship. As explained previously, Islamic literature functions to guide Man to recognise and reaffirm Allah SWT as the Creator and God of all universes as well as to guide man to seek knowledge. As such, man can position himself on the path of truth and justice (Mohd Affandi, 1992, p. 23). Narrating the physical intimacy between a married couple in literature hinders the role of knowledge that instead should prioritise propriety and intelligence and allow someone (who routinely reads literary works) to become an intellectual with high regard for intelligence. The depiction of false realities such as sensual and sexual behaviours can only reflect desire, shallowness, pettiness, confusion, mimesis and hedonism. In fact, Fahri's role as a husband who fails to shoulder the responsibility of fulfilling his wives' sexual needs can also be regarded as a failure even after the conscious effort made by Aisha and Hulya to arouse his desire.

The analysis of the novel, Salju Sakinah (henceforth referred to as SS), shows that Sumayyah cultivates romantic feelings from her secondary school days until university. However, she communicates with her boyfriend, Afnan, via letters for seven years because she is studying in Jordan while he is studying in Egypt (SS, pp. 34-35). Sumayyah's love for Afnan ends midway when Afnan chooses another girl to be his wife (SS, p. 12). This separation allows Sumayyah to be courted by other man. This study witnesses a similarity between Fahri and Sumayyah in attaining romantic love, as both of them have received more love rather than persevere to earn it. $A A C 2$ shows Aisha's and Hulya's determination to love and to make Fahri desirous in bed while Sumayyah is pressured by romantic proposals from Luqman and Naufal. 
However, this study sees that $S S$ further highlights the feelings of emotional love compared to physical love. As a student of Islamic Studies at Yarmouk University (SS, p. 15) who is active in student societies $(S S, 4)$, Sumayyah restricts her socialisation with male students even though she has written love letters to Afnan for seven years (SS, 34-35). Their intimacy is shown when Sumayyah receives her final letter from Afnan:

Afnan. Satu nama yang sedaya upaya cuba dilupakan. Namun apalah dayanya; nama yang sudah berzaman menghiasi kamar hati, dan wajah yang sekian lama tersimpan di memori ingatan, masakan boleh dikikis dalam tempoh sehari. Dia memerlukan masa. Lantaran kenangan dihimpun dan mawaddah (cinta) yang dipupuk bukan berusia sebulan dua, tetapi lebih tujuh tahun!

[Afnan. One name to forget to the best of one's ability. However, what can one do; a name that for centuries has adorned a heart's chamber, and a face that has been kept locked in one's memory for a long time, how can these be erased in just a day. One requires time. Because memories are gathered and love that is nurtured not just for one or two months but for more than seven years!]

Sumayyah uses her understanding of tauhid (oneness of Allah) and knowledge that she learnt in order to face the test of separation from Afnan. When Afnan's face appears in her mind, she prays to Allah SWT (SS, p. 36). In the context of reminiscing the man she loves, $S S$ depicts Sumayyah's behaviour from recalling physical aspects excessively in contrast to such depictions in $A A C 2$. For example, when he imagines Aisha's face, Fahri remembers their sexual encounters and recounts Aisha's physical actions towards him. The concept of the nature and function of literature prohibits false reality that disregards truth as revealed by Mohd Affandi (2002, p. 47):

Hasil seni (yang berunsurkan realiti) atau kemahiran yang sempurna, yang tinggi kemahirannya, boleh memperdayakan manusia dan meletakkannya dalam sejenis ilusi, khayalan liar, yang menjauhkannya daripada fitrahnya.

[The product of art (which is based on reality) or a perfect skill, can deceive man and place him in a type of illusion, wild imagination, which distances him from his natural disposition.] 
Even though Fahri remembers his wife, the physiological depiction that is based on sex does not fulfil the function of Islamic literature. This is because women ought to be portrayed in terms of their mind, knowledge, devotion to prayer, self-respect and dignity as a human being and not be treated as an object or commodity (Ungku Maimunah and Zulkarnain, 2013, pp. 74-75). Sumayyah's first meeting with Naufal often occupies her mind to the point of remembering his physical identity: the man with thick eyebrows donning a Raihan-type skullcap (SS, p. 100). She is keen to know Naufal better but is hindered by her shyness (SS, p. 101). She cannot deceive herself; she is pleased with Naufal's presence. This is evident when she smiles to herself upon looking at the place where they first met (SS, p. 157). In fact, her heart throbs each time she encounters Naufal: "Naufal! Perlahan-lahan dia menjawab salam. Segera menunduk kembali. Tidak semena-mena dadanya berdetak agak kencang. Entah mengapa Naufal!" [Slowly she responds to his greetings. Hastily, she bows again. Without any rhyme or reason, her chest heaves rapidly. Not sure why] (SS, p. 159).

Sumayyah's attitude of suppressing her romantic feelings is consonant with the nature and function of literature, which elevates the dignity of women in the novel. Ungku Maimunah and Zulkarnain (2013, p. 76) states that Islamic literature focuses on women characters who have a perfect mind, are not overwhelmed by their emotions until they lose their human nature as well as not allowing themselves to be treated as an object, commodity and be easily manipulated. Moreover, a woman's modesty includes her physique, thoughts, manners, and refrain from anything vulgar and excessive. Islamic literature does not transgress the abovementioned concept, including the reluctance to depict unrestrained marital relationship as found in $A A C 2$.

Subsequently, Sumayyah is also projected as someone who does not easily accept any man's love. Although she is disappointed with Afnan and is timid about getting to know Naufal better, her heart is adamant in not accepting Luqman's marriage proposal. Sumayyah rejects Luqman's marriage proposal through wisdom gained by performing istikharah prayers, stating her stand forthrightly (SS, p. 388) as well as introducing her close friend, Nasriah, to be Luqman's wife (SS, p. 365). In this context, Sumayyah, to the best of her ability, restrains herself from repeating the relationship that she had with Afnan.

Rejecting Luqman brings Sumayyah closer again to Naufal. Through a third party, Hakimi and his wife Hakimah, Naufal seeks Sumayyah's hand in marriage. The ensuing process is taaruf or close acquaintance between 
Sumayyah and Naufal. Without being critically opinionated, Sumayyah believes that Naufal is a man of charisma and confidence. Hence, she does not need to explain her feelings directly to him: "Apakah ertinya saya datang berjumpa ustaz di sini pada malam ini? ["What is the meaning of my meeting the ustaz here tonight?"] (SS, p. 518).

The above statement posits Summayah as a polite and knowledgeable Muslim woman. In fact, Naufal informs of Sumayyah's acceptance with a sense of gratitude and modesty. To avoid negligence, they were married within a few weeks after knowing each other (SS, p. 529).

The romantic relationship between Sumayyah and Naufal becomes more evident after they are declared husband and wife. Summayah calls her husband abang as opposed to ustaz when he was still a bachelor (SS, p. 530). Having just enjoyed their consummation, they feel desirous and happy. Sumayyah's physical intimacy is shown in the way she touches and kisses Naufal's hands as well as smiling sweetly at him. Naufal, on the other hand, strokes Sumayyah's hair and kisses her crown. Their enwrapped feelings are depicted as follows: "Mata bertentang mata. Lama. Kata-kata sirna entah ke mana. Debar kekal memalu dada" [Eyes locked. Long. Words disappear without a trace. Flutters still strike the chest] (SS, p. 532).

This study finds that the cold attitude of Sumayyah towards men when she was single changes as she becomes loving after marriage. This change is shown by her unwillingness to eat while waiting on Naufal and her restlessness when he does not return home (SS, p. 547). In fact, she would ready herself with a captivating smile and attractive clothes and perfume for her husband (SS, p. 548). Such a portrayal of Sumayyah reflects the responsibility of a wife. Although Aishah and Hulya practise ways to allure their husband, Fahri, the physical depiction that is projected in $A C C 2$ does not match with the concept of the nature and function of literature as it transgresses the bounds of women's modesty in literature and details on a woman's beauty beyond Islamic limits to the extent of arousing the reader's desire. Literature must present woman's beauty in an indirect manner through symbolism, simile and with emphasis on decency.

In fact, $S S$ better promotes the character of a Muslim woman when tested on her married life compared to her role in only arousing the sexual desire of her husband, as observed in $A A C 2$. When Sumayyah is informed of a horrible accident at the same place and time her husband is there, she recites prayers, reads the Qur'an several times and performs prayers $(S S$, pp. 550-552). Sumayyah submits to the will of Allah SWT and has no negative 
thoughts. The moderation employed in the physical projection of Sumayyah conforms to the aims of literary writing, which is to teach good behaviour to Man and also to avoid dishonour arising from reading such literature.

\section{CONCLUSION}

In conclusion, this study finds that $S S$ and $A A C 2$ promote the concept of marital romantic love. $A A C 2$ focuses on the character of Fahri as a man who is loved by Aisha and Hulya. He is a passive receiver, very much in contrast to Aisha and Hulya, who both appear to be active in arousing a sense of love in their marital relationship. SS, on the other hand, promotes the character of Sumayyah who is presented with marriage proposals from two men, Luqman and Naufal. After becoming a wife, Sumayyah is depicted as being active in developing a cordial relationship with her husband. However, when compared to $S S, A A C 2$ is inclined to focus on the physical and sexual aspects of a marital relationship to the extent of smearing the nature and function of literature.

Finally, this study discovers that the market demand prefers elements of physical love that, in turn, causes romantic love in both novels to still repeat the earlier tradition of Islamic novels, as previously discussed. Before Indonesia's independence, its society consistently preferred romantic love based on physical and sexual intimacy. However, this does not conform to the concept of the nature and function of literature, which emphasizes on moderation and good behaviour towards the reader.

\section{ACKNOWLEDGMENT}

This work was supported by Hankuk University of Foreign Studies Research Fund of 2018.

\section{NOTES}

1. All Qur'anic citations and interpretations are taken from Tafsir Al-Azhar (2018) by Hamka, published by PTS Publishing House Sdn. Bhd.

2. During this time, Islamic civilisation was under the rule of Caliphate Bani Abbasutag and was named the Arab Middle Ages. In this era, there were occurrences of cultural assimilation between Arab-Islam and worldly cultures as noted by Md. Ataur Rahman (2010, p. 59): "It was the second renaissance that Arabs established by their mutual contact and assimilation with Persian, Roman, Indian, Spanish etc. This endeavour is also linked with religio-cultural assimilation, particularly by means of translation of 
Greek philosophy and sciences, Persian history, their civilization and Indian philosophy and their styles transformed into Arabic."

3. Hamka recognized modern Arab Literature, especially from Egypt, when he was in Mecca in 1927. The Egyptian writer who had a major influence over novels was AlManfaluthy. Hamka wrestled with all creative writings of Luthfy Mustafa for a large part of his life until he was called Manfaluthy of Indonesia (Gerard Moussay, 1986, p. 91).

4. The spread of popular novels in Indonesia was caused by the development of general magazines and newspapers throughout Indonesia such as Pikiran Rakyat newspaper in Bandung, Kedaulatan Rakyat and Berita Nasional in Yogjakarta, Suara Merdeka and Angkatan Bersenjata in Semarang, Surabaya Post in Surabaya, Suara Indonesia in Malang, Waspada in Medan, Haluan in Padang, Kompas, Sinar Harapan, Merdeka, Indonesia Raya and Suara Karya in Jakarta. All newspapers and magazines have space for short stories and serial stories that are based on society's popular stories. This further reinforced popular fiction in Indonesia (Yudiono K.S., 2007, p. 220).

5. In 1982, the Terengganu Islamic Foundation (YIT) for the first time organised a competition to write Islamic novels. This sponsorship opened up a serious space for the development of Islamic-based novels in Malaysia in the ensuing years (Kamariah, 2011, pp. 70-71).

6. Among the publishers who published a lot of Islamic reading materials are Pustaka Panjimas, Bulan Bintang, al-Maarif, Penerbit Mizan, Gema Insani Press and Republika (C.W. Watson, 2005, pp. 177-210). From the 1960s until the early 1990s, literary works based on Islam and love were written in the forms of poetry, short stories and theatre. The setting up of the Islamic Cultural Artists Council (MASBI) in 1961 further animated literary activities with Islamic features through theatre and poetry (Mohd Faizal Musa, 2012, pp. 41-53).

7. This idea offers literary terminology that symbolises high knowledge behind literature. This terminology is suitable to be linked to the concept of stories as a tool to develop high discourse and imagination. Its founder, Mohd Affandi Hassan, regards literature as a form of original Malay literature that focuses on aspects of content delivery compared to external form or speech. Its system is divided into three areas: (i) realm of story, (ii) non-story realm and (iii) rule domain. All these domains emphasise on aspects of didactic and moral behaviour as in Malay Islamic literature in the 16th and 17th centuries. This idea releases the dependence on Western theories that have spearheaded modern Malay literary theories and conversely wishes to reclaim the original Malay-Islamic literary tradition. 


\section{REFERENCES}

A. Ubaidillah Alias. (2008). Warkah Cinta Berbau Syurga. Penerbit : PTS Millennia Sdn Bhd.

A. Ubaidillah Alias. (2013). Kala Cinta dan Wahyu Bersatu. Kuala Lumpur: PTS Millennia Sdn Bhd.

Anif Sirsaeba El-Shirozy. (2006). Fenomena Ayat-ayat cinta. Jakarta: Penerbit Republika.

Arnez, Monika. (2009). Dakwah by the pen: Reading Helvy Tiana Rosa's Bukavu. Indonesia and The Malay World 37:107, 45-64.

Banks, David J. (1987). From class to culture, social conscience in Malay novels since independence. New Heaven: Yale University Southeast Asia Studies.

Basma Dajani dan Hala Khalidi. (2012). The literature of love by three theologians in the Arab Islamic tradition. Elsevier 82:2013, 226-231, 2014.

Smith, Charles D. (1979). Love, passion and class in the fiction of Muhammad Husayn Haykal. Journal of the American Oriental Society 99 (2), 249-261.

Dian Nathalia Inda. (2015). Memang jodoh: Pemberontakan Marah Rusli terhadap tradisi Minangkabau. Kandai 11:2, 217-233.

Frost, Simon R. (2012). The business of the novel: Economics, aesthetics and the case of middlemarch. London and New York: Routlegde.

Ghada Alghamdi. (2013). East Meets West: The Impact of British Novelist upon Modern Arabic Fiction. (Unpublished Masters Disertation). Universiti Arkansas State, Arkansas.

Habiburrahman El-Shirazy. (2004). Ayat-ayat cinta. Jakarta: Penerbit Republika.

Habiburrahman El Shirazy. (2007). Ketika Cinta Bertasbih. Volume 1. Jakarta: Penerbit Republika.

Habiburrahman El Shirazy. (2007). Ketika Cinta Bertasbih. Volume 2. Jakarta: Penerbit Republika.

Habiburrahman El Shirazy. (2008). Dalam Mihrab Cinta. Jakarta: Penerbit Republika. Habiburrahman El Shirazy. (2010). Bumi Cinta. Al-Hidayah Publication.

Habiburrahman El Shirazy. (2011). Cinta suci Zahrana: (sebuah novel pembangun jiwa). Al-Risalah Product Sdn Bhd.

Habiburrahman El Shirazy. (2015). Api tauhid: cahaya keagungan cinta sang mujaddid: novel sejarah pembangunan jiwa. Jakarta: Penerbit Republika.

Habiburrahman El-Shirazy. (2015). Ayat-ayat cinta 2. Jakarta: Penerbit Republika. Hamka. (2018). Tafsir al-Azhar juzuk 19. Selangor: PTS Publishing House Sdn. Bhd. Ilham Hamdani. (2008). Hidayah Cinta. Kuala Lumpur: PTS Millennia.

S.K, Ishadi. 2011. Negotiating mass media interest and heterogeneous Muslim audiences in the contemporary social-political environment of Indonesia. In Andrew N. Weintraub, (ed.). Islam and popular culture in Indonesia and Malaysia. London: Routledge. 
MALAY LITERATURE VOLUME 31 NUMBER 1 JUNE 2018

Kamariah Kamarudin. (2011). Takmilah dalam novel Melayu. Kuala Lumpur: Dewan Bahasa and Pustaka.

Khairallah As'ad. (1980). Love, madness and poetry an interpretation of the Magnun legend. Beirut: Visual Library.

Kern, Stephern. (1992). The culture of love Victorian to moderns. England: Harvard University Press.

Leon Salim. (2010). Prisoners at Kota Kane (Traslator by Audrey Kahin). Singapore: Equinox Publishing (Asia) Pte. Ltd.

Levy, Isabelle Charlotte. (2013). The poetics of love in prosimetra across the medieval Mediterranean (unpublished Ph.d. Dissertation). Cambridge: Harvard University. Maier, H.M.J. (1993). Beware and reflect, remember and recollect: Tjerita Njai Soemirah and the rmergence of Chinese Malay literature in the Indies. Journal Bijdragen tot de Taal-, Land- en Volkenkunde, Deel 149(2),1993.

Md. Ataur Rahman. (2010). A study of Adab Belles- Lettres during Abbasid period from 750 A.D to 1258 A.D. Assam: University of Gauhati.

M. Quraish Shihab. (1996). Wawasan al-Quran. Bandung: Mizan.

Moch Yunus. (2015). Sastra (Puisi) sebagai kebudayaan bangsa Arab. Humanistika 1(1), 1-14.

Mohd Affandi Hassan. (1992). Pendidikan estetika daripada pendekatan tauhid. Kuala Lumpur: Dewan Bahasa and Pustaka.

Mohd Affandi Hassan, Ungku Maimunah Mohd Tahir \&Mohd Zariat Abdul Rani. (2008). Gagasan Persuratan Baru: Pengenalan dan Penerapan. Bangi: Institute of the Malay World and Civilisation (ATMA) Universiti Kebangsaan Malaysia.

Mohd Faizal Musa. (2012). Fenomena sastera Islam di Indonesia. International Journal of the Malay World and Civilisation 30(1), 41-53.

Mohd Zariat Abdul Rani. (2011). Seksualiti dalam novel Melayu. Bangi: Penerbit UKM.

Mohd Zariat Abdul Rani. (2012). Islam, romance and popular taste in Indonesia: A textual analysis of Ayat-ayat Cinta by Habiburrahman El-Shirazy and Syahadat Cinta by Taufiqurrahman Al-Azizy. Indonesia and The Malay World 40:116, 59-73.

Mohd Zariat Abdul Rani. (2014). The conflict of love and Islam: The main ingredients in the popular Islamic novels of Malaysia. South East Asia Research 22(3), 417- 433.

Moussay, Gerard. (1986). Une grande figure de l'Islam Indonésien: Buya Hamka. Archipel, 32, 87-111.

Mujiyanto, Yant dan Amir Fuady. (2014). Kitab sejarah sastra Indonesia. Yogjakarta: Penerbit Ombak.

Nurazmi Kuntum. (1991). Teori dan pemikiran sastera Islam di Malaysia. Kuala Lumpur: Dewan Bahasa and Pustaka. 
Pavlin, James D. (1998). The concept of 'ubudiyyah in the theology of Ibn Taymiyyah: The relationship between faith, love and actions in the perfection of worship (Phd Dissertation). New York: New York University.

Pomerantz, Maurice. (2015). Reading love and friendship at the Abbasid Court. Accessed: http://hdl.handle.net/2451/33977

Rosni Samah. (2013). The thought of islamic literature in modern Malaysian literature. International Journal of Social, Behavioral, Educational, Economic, Business and Industrial Engineering 7:4, 1082-1088.

Rosni Samah dan Normazla Ahmad Mahir. (2013). A correlation study between the theme of Egyptian novel "Zaynab" and Malaysian novel "Faridah Hanom". International Journal of Humanities and Social Science 3 :12, 139-144.

Salina Ibrahim. (2008). Bukan Yang Pertama. Kuala Lumpur: PTS Millennia.

Teeuw. A. (1967). Hamka as a novelist. Modern Indonesian Literature 69-72. Accessed: https://doi.org/10.1007/978-94-015-0768-4_28.

Thoyba Mursyidah. (2014). Kuntum Cinta di Taman Syurga. Kuala Lumpur: PTS Millennia.

Ungku Maimunah Mohd Tahir dan Zulkarnain Mohamed. (2013). Islam, feminisme Barat dan sastera Melayu. Bangi: Penerbit UKM Press.

Weintraub, Andrew N. (2011). Islam and popular culture in Indonesia and Malaysia (Edited by Andrew N. Weintraub). New York: Routledge.

Watson, C.W. (2005). Islamic book and their publisher: Notes on the contemporary Indonesian scene. Journal of Islamic Studies 16:2, 177-210.

Yeni Mulyani. (2010). Nasionalisme dalam Siti Nurbaya karya Marah Rusli. Jurnal Sosioteknologi 9:19, 797-811.

Yudiono K.S. (2007). Pengantar sejarah sastera Indonesia. Jakarta: Penerbit PT Grasindo.

Zaid Akhtar. (2008). Salju Sakinah. Selangor: PTS Publication.

Received: 2 October 2017

Accepted: 12 Mei 2018 